advent of the cellulose-finished motor-car body has led to the demand for hard, high gloss polishes with a quick effect, which demand has resulted in a large number of new types of formulæ.

The proof, however, of the value of a book of formulæ lies not only in the ingredients, but also in the description of the exact working conditions and correct manipulation without which most technical formulæ are useless. The book does appear to satisfy this requirement, and moreover each section is preceded with a monograph discussing the development and modern requirements of the preparations concerned.

H. B.

\section{A Bibliography of Sir James George Frazer, O.M.} Compiled by Theodore Besterman, with Portraits and Facsimiles, and a Note by Sir J. G. Frazer. Pp. xxi $+100+3$ plates. (London: Macmillan and Co., Ltd., 1934.) 12s. 6d. net.

THIs bibliography of the works of Sir James Frazer has been produced by the subscription of friends and admirers and under the ægis of the Folklore Society in celebration of his eightieth birthday in January last. The work of Sir James Frazer is too well known for this list of his books, essays, lectures and addresses to call for extended comment. It chronicles a remarkable achievement. It may, perhaps, come as a surprise to those who are not intimately acquainted with the extent and variety of his writings to find that although "The Golden Bough" bulks large, it by no means expresses the whole of his interests, nor, notwithstanding its many editions, has it absorbed one tithe of the apparently boundless store of energy upon which he has drawn in the fifty-five years of his life as an author. "The Golden Bough" is extensive enough to have been the life-work of any ordinary individual-assuming that he had the genius to conceive it. Yet Sir James in his "Totemism and Exogamy", his "Folklore of the Bible" and his study of immortality has produced three major works, any one of which would have taxed the industry and made the reputation of a research worker.

The bibliography has been admirably produced and is illustrated with excellent portraits of Sir James and with facsimiles which show his method of working. The first page of the list is marred by a misprint, the editor having fallen into the familiar schoolboy trap of "Cataline".

The Woodlands and Marshlands of England. By H. A. Wilcox (Mrs. G. S. Treleaven). Pp. 55+2 maps. (Liverpool: University Press of Liverpool ; London: Hodder and Stoughton, Ltd., 1933.) $6 s$. net.

The University Press of Liverpool has recently published two maps of the woodlands and marshlands of England prepared on the researches of H. A. Wilcox. These are founded on several years of research, which was assisted by the British Association. The first map is founded on geological, climatic and topographical evidence, and the second is drawn from the evidence deduced from early literature. To these have been added a discussion of the problems involved and of some of the regional questions. The first map involved considerations of the underlying rocks and their soil covering, of the surface configuration of relief, height and aspect, and of the climatic conditions, which as yet are not sufficiently determined even in the immediate past. But all three of these act together, or in opposition, to provide the area which was woodland-covered, or heath, or bare grassland. Then again, woodlands may destroy themselves by the accumulation of their decaying materials and by holding up water, changing lands into marshes. Many areas can be only tentatively mapped, awaiting the local research of counties. The corrections made thereby are essential to this study, and it is requested that they be communicated to Prof. Roxby of the University of Liverpool. The subject is an important one, for it is basal to the study of early man in Britain, determining his track ways and early settlements.

Grundriss der physikalischen Chemie. Von Prof. Arnold Eucken. Vierte Auflage. Pp. xxiii +699 . (Leipzig: Akademische Verlagsgesellschaft m.b.H., 1933.) 29 gold marks.

THE third edition of Eucken's 'Grundriss der physikalischen Chemie" was merged in a "Lehrbuch" of 1,000 pages, issued in 1930 (NATURE, Dec. 27,1930 , p. 988 ) ; but even then the project existed of splitting the product into two parts, the more general and elementary part being issued as a fourth edition of the "Grundriss" and the more special and advanced part as a second edition of the "Lehrbuch". The first portion of this project has now been carried out, and has yielded a volume of 700 pages with 179 instead of 250 figures. The tables and figures have been taken for the most part from the "Lehrbuch", but the text has been condensed by omitting much descriptive matter (for example, Aston's mass-spectrograph) and concentrating on fundamental laws. Numerical exercises have also been added at the ends of certain chapters.

Science and God. By Bernhard Bavink. Translated by H.Stafford Hatfield. Pp. ix +174 . (London: G. Bell and Sons, Ltd., 1933.) 5s. net.

Is recent years, fundamental changes have taken place in all the assumptions upon which philosophical and religious discussions are based. The author makes the point that mechanistic physics by no means implies atheism and materialism as a necessary consequence; and that the so-called neutrality of science with regard to religious questions is no more an axiom of procedure. In fact, the old materialistic arguments, still put forward in free-thinking circles, will be found to be out-of-date doctrines in the light of a correct interpretation of the results of present-day science.

T. G. 